DOI:

Л.В. ФАДЕЕВ, канд. техн. наук. доцент, директор

ООО "Спецэлеватормельмаш"

\title{
ТОЧНАЯ АГРОТЕХНОЛОГИЯ БУДУЩЕГО НАЧИНАЕТСЯ СЕГОДНЯ. КУКУРУЗА
}

Динамика прогресса в агробизнесе позволяет утверждать, что в первой половине XXI века точная агротехнология станет абсолютной нормой на всех континентах по той простой причине, что она позволяет поднять эффективность использования земли. Точная агротехнология - это точное земледелие, равнораспределенное размещение растений на поле и точный высев сильных семян, обеспечивающих количество растений перед уборкой, практически, равное количеству высеянных семян, т.е. точная норма высева сильных семян в ит.кг/га.

Точное земледелие уже доказало свою технологическую и экономическую состоятельность, и это произошло сравнительно быстро по той причине, что для внедрения потребовалась только наземное навигационное оборудование и незначительная доработка серийно выпускаемых машин, поскольку глобальная спутниковая система слежения за движением объектов была отработана военно-промышленным комплексом.

Точный высев при равнораспределении растений на поле требует серьезной модернизации не только посевной техники, но и техники для сопровождения процесса роста растений и уборочных комбайнов (жаток). А что касается щцадящей пофракционной технологии производства сильных семян, то это, вообще, технология, которая придет на смену существующей травмирующей и однофракционной. Тем не менее, мотивация внедрения точной агротехнологии лежит в повышении прибыльности земледелия.

Именно это мы рассмотрим на трех культурах чрезвычайно значимых сегодня для Украины - кукурузе, подсолнечнике и сое. В начале рассмотрим какое непреодолимое препятствие ждет агробизнес на пути дальнейшего повышения урожайности.

Общая неоспоримая задача агробизнеса - эффективное использование с/х угодий при поддержании, а в перспективе, повышении плодородия почвы.

Для рассмотрения вопроса возьмем единицу объема среды обитания, в которой начинается жизнь растения и протекают все фазы его развития и формирование урожая. Для анализа необходимо разделить объем на две части: надземную и почвенную (рис.1).

Задача по размещению растений на поле сводится к тому, чтобы растение по максимуму использовало все необходимое для продуктивного развития, как с надпочвенного объема, так и с самой почвы, не создавая конкуренции соседним растениям.

Урожайность поля зависит от потенциала отдельно взятого растения, но она зависит и от «ко- мандного» результата, т.е. от всех вместе взятых и соседствующих друг с другом растений. Вот здесь-то их распределение на поле и играет важнейшую роль.

Сегодня этот вопрос становится особенно актуальным, поскольку природный потенциал продуктивности основных сельскохозяйственных культур в развитых странах практически исчерпал свои генетические возможности. Специалисты объясняют такое снижение темпа роста урожайности предельной возможностью растения использовать солнечную энергию, т.е. при полном обеспечении растения всем необходимым для его развития и продуктивности ограничение оказалось в КПД фотосинтеза. Фотосинтез главный процесс накопления биомассы. Поэтому, чрезвычайно важно распределить растения на поле так, чтобы свести к минимуму их взаимозатенение.

Настало время тщательного рассмотрения существующей агротехнологии отдельных культур и выявления не использованных ресурсов. Оптимизация размещения растений на поле относится $к$ таким ресурсам. Рассмотрим это утверждение на примере кукурузы.

Так сложилось, что необходимость борьбы с сорняками на посевах кукурузы, вначале вручную, а в последствии механической обработкой междурядья, предопределила технологию высева семян кукурузы в ряд с расстоянием между рядами равным $70 \mathrm{~cm}$. Под эти условия были созданы все машины для сева, обработки и уборки кукурузы. При разной густоте сева кукурузы при таком междурядье расстояния между растениями в ряду изменяется от $28 \mathrm{~cm}$ до $14 \mathrm{~cm}$ (рис.2).

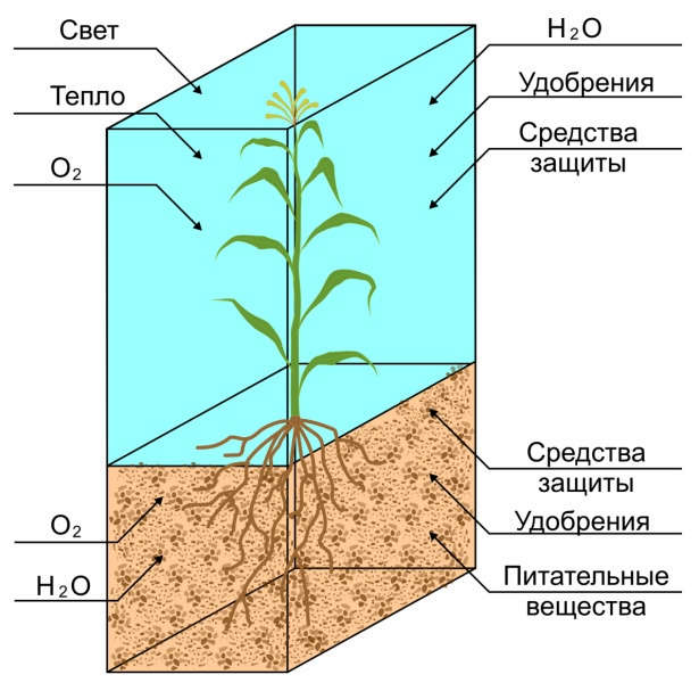

Pис.1. Среда обитания и поступаемые компоненты для жизни растения. 


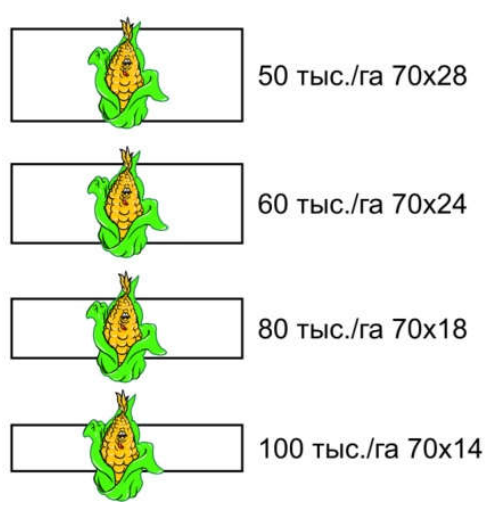

Рис.2. Сужение зоны питания растения кукурузы при увеличении густоты в ряду.

Ясно, что при таком размещении растений на поле, имеющийся ресурс света, воды, питательных веществ используется не в полной мере. Получается, что при таком распределении растений мы обрекаем их на взаимоконкуренцию за свет в надпочвенном объеме, и за воду, кислород, удобрения, питательные вещества их корневых систем.

В этом вопросе есть еще один важный момент, но для его пояснения необходимо рассмотреть физику теплообмена между солнечной радиацией и незатененной частью поля.

Если рассмотреть энергосистему «СолнцеЗемля» без учета атмосферы, то все выглядит сравнительно просто - поток лучистой энергии от Солнца на Землю, приходящийся на $1 \mathrm{~m}^{2}$ ее поверхности по нормали к солнечным лучам равен $1330 \pm 3 \% \mathrm{Bm} / \mathrm{m}^{2}$ (рис.3).

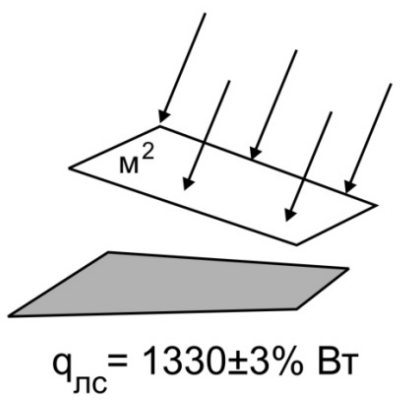

Рис.3. Количество солнечной энергии, приходящейся на 1 кв.м. поля по нормали к солнечным лучам.

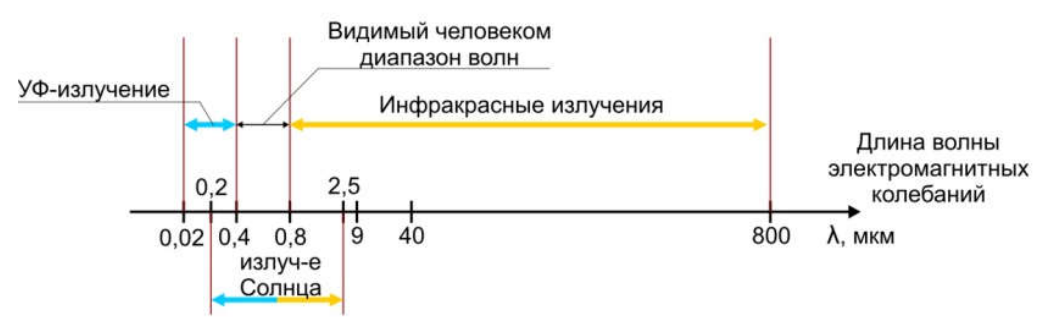

Рис.4. Виды излучений по длине волны, $\lambda$, мкм.

Если бы не атмосфера, то можно было бы рассчитать температуру в каждой точке Земли в зависимости от времени суток и года. Именно такие точные расчеты выполнены астрофизиками для других безатмосферных планет. А на нашей Земле, синоптики, даже при сегодняшнем мониторинге всех значимых параметров атмосферы, объединенных в единую глобальную систему обработки, не в состоянии дать надежный прогноз более чем на 10 дней. Все дело в случайных событиях, основным из которых является экранирование облачностью различных участков поверхности Земли. Облачность над лесом - одна картина теплообмена в этом месте, над морем - другая, над горами - третья и т.д. Предсказать эти случайные по времени и месту экранирования солнечных лучей невозможно. Таким образом, засухи, как и наводнения на четырех материках Земли (Антарктида не в счет) были, есть и будут.

Миллионы лет на Земле растения и животные в процессе эволюции научились защищаться от крайних проявлений засухи. В любом лесу (хвойном и лиственном) земля всегда покрыта растительными остатками с прошлого сезона. Почвенные микроорганизмы перерабатывают значительную их часть, но природа регулирует этот процесс так, что земля в обязательном порядке остается покрытой. Это оказывается очень важным моментом - природа как бы не допускает прямого попадания солнечных лучей на открытую землю в зоне растительноcmu.

Часто для объяснения какого-либо неявного, сложного физического процесса помогают простые аналоги, понятные на бытовом уровне. Применим этот прием. Человек в сауне перегревается за счет контакта с воздухом, нагретым от камней, лежащих на нагревателе. Камни нагреты, и человек кроме горячего воздуха ощущает еще и поток тепла, попадающий на его кожу как бы от невидимых лучей, идущих непосредственно на него от нагретых камней. Не как бы - а все так и есть. Поток инфракрас$\boldsymbol{\mu b \boldsymbol { x }}$ лучей невидимых человеческим глазом (человек видит в узком диапазоне электромагнитных волн 0,4 - 0,8 мкм, а ик-излучения лежат в диапазоне 0,8 800 мкм) (рис.4) пронизывает воздух со скоростью света и нагревает тела, попадающиеся на его пути. Причем, ик-излучения способны нагревать тела в большей мере (высокая энергонесущая способность ик-волн лежит в диапазоне 40 мкм), чем более короткие и более длинные волны. Но это еще не все.

Объясню следующий парадокс. Вылитый ковш холодной воды на раскаленные камни сауны охлаждает их, а испарение воды с их поверхности (по закону физики) еще более усугубляет их охлаждение, а температура при этом в сауне резко возросла. Точнее не температура воздуха, а нагрев предметов (включая человека). Объяснение этого парадокса в следующем.

Одноатомные и двухатомные газы (а именно из них состоит воздух - смесь $\mathrm{N}_{2}$ и $\mathrm{O}_{2}$ ) не поглощают лучистую энергию и не излучают ее, а трехатомные газы $\mathrm{H}_{2} \mathrm{O}$ и $\mathrm{CO}_{2}$ ведут себя в лучистом потоке как твердые частички и, будучи нагретыми (от камней каменки в нашем случае), излучают тепловой поток (рис.5).

Именно поэтому человек почувствовал, что «жару добавилось» (хотя температура воздуха в сауне чуть снизилась). Как же человек (особенно завсегдатай сауны) продолжает рассказывать анекдоты 


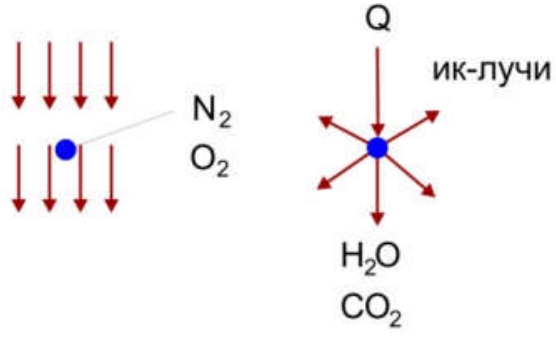

Pис.5. Свойства двух- и трехатомных газов по поглощению излучения.

соседям по пологу в среде выше $100^{\circ} \mathrm{C}$ (рекорд около $\left.170^{\circ} \mathrm{C}\right)$, да все просто - активное удаление воды из организма человека, через испаряющийся пот с поверхности кожи, удерживает температуру тела в допустимых пределах (тепловая энергия расходуется на разрыв связей между молекулами при переходе воды из жидкого состояния в сухой пар).

Tenерь к растениям. Если солнечные лучи попадают на почву между растениями, то эти участки быстро нагреваются до температуры выше окружающего воздуха. Быстрый нагрев почвы обусловлен двумя причинами. Солнечные лучи избирательно нагревают тела в зависимости от их цвета - темные нагреваются в большей мере, нежели светлье, а кроме того, неравномерность поверхности почвы увеличивает освещенную площадь и она, практически, не отражает солнечные лучи, т.е. по отношению к солнечным лучам почва близка к понятию «черного тела» (все лучи поглощает). Будучи нагретой от поглощенных солнечных лучей эта часть почвы излучает тепловой поток уже в диапазоне ик-волн на листья растений с нижней стороны. Вот тут, как говорится, мы природу подставили. Как известно, испарение воды с поверхности листа (транспирация) происходит через устьица листа и природа "спрятала" их от попадания прямых солнечных лучей на нижнюю сторону листа. Так вот, именно на нижнюю часть листа идет поток ик-излучений от нагретого участка почвы. Кроме того, в физике известно, что длина волны равная 9 мкм (она лежит в диапазоне ик-излучений) вызывает резонансные колебания молекул $\mathrm{H}_{2} \mathrm{O}$, что, в свою очередь, вызывает интенсивное испарение воды с поверхности тела. Интенсивность транспирации - количество испаренной воды в г за час с площади дм², может изменяться в зависимости от условий, в которых оказалось растение, в 10 раз (от 0,15 до 1,5 г,час/дм ${ }^{2}$ ). И если учесть дополнительный тепловой поток от ик-излучения молекул $\mathrm{CO}_{2}$ и воды, и количество испаряемой воды с 1 га за вегетацию (пшеницы около 2 тыс.тонн, кукурузы 3,2 тыс.тонн, подсолнечника более 4 тыс.тонн), то становится понятно, какую сауну человек уготовил растению в засуху (рис.6). Чем меньше поверхность поля доступна для прямых лучей, тем легче растению перенести засуху. Борьба за выживание заставляет растения интенсивно испарять воду, так что разница температуры живого листа и мертвого при прочих равных условиях в солнечный день достигает $5-7^{\circ} \mathrm{C}$. Как надо растению испарять воду, чтобы держать такую разницу? В естественной среде растение в таких условиях не оказывается.

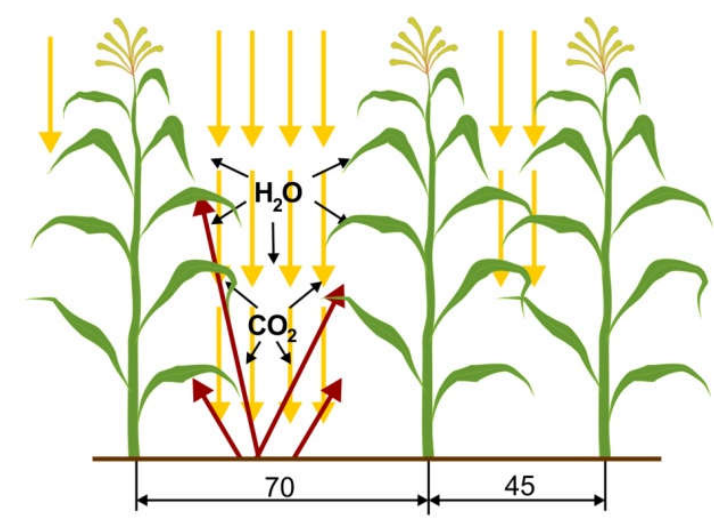

Рис.6. Схема теплового баланса при междурядьях 70 и 45 см.

Как было сказано, чем меньщая поверхность поля доступна для прямых солнечных лучей, тем легче растению перенести засуху. Для кукурузы это особенно значимо, ибо поток ик-излучений от перегретой почвы попадает на нижнюю часть листьев, поверхность которых у одного растения достигает 4 $\mathrm{M}^{2}$ на $1 \mathrm{~m}^{2}$ поля.

Несколько слов о значимости поступающей энергии от солнца на образование и накопление биологически питательных веществ. Чем больше листовая поверхность работает как «фабрика утилизации солнечной энергии», тем мощнее растение.

Что касается низкой продуктивности при ширине междурядья 70 cм, то оно легко объясняется. Растения скучены в рядах, что усиливает конкуренцию между ними за влагу, свет и питательные вещества уже в ранний период жизни, что при одинаковых факторах внешней среды сдерживает возможность повышения урожайности.

Широкое междурядье создает благоприятные условия для развития сорной растительности. Поэтому для уничтожения сорняков необходимо проводить междурядные обработки, при которых травмируются верхние тонкие корешки, обеспечивающие использование влаги даже при незначительных осадках.

В свете всего вышесказанного, необходимо максимально помогать растению в его жизнедеятельности, что и является целью агротехнологии. Конкуренция растений за влагу (влага несет питательные вещества) начинается уже с фазы бутонизации и далее только усиливается вплоть до созревания. Оптимальное размещение растений в поле позволяет в большей мере развить корневую систему, а значит и продуктивность растения.

При равномерном размещении улучшается освещение каждого растения и повышается продуктивность фитоценоза. Что касается КПД использования солнечной радиации, т.е. уровня усвоения ФАР, то, если для большинства растений он близок к $2 \%$, то у кукурузы этот коэффициент близок к $3,5 \%$. Требуется только не затенять растение.

Итак, резюме - не заставляйте растения тратить энергию на борьбу друг с другом.

Таким образом, исходя из чисто линейных и площадных оптимизаций, можно утверждать, что при севе кукурузы, с целью получения максимального урожая, необходимо равномерно распределить рас- 
тения на поле. Такое размещение позволяет обеспечить равноудаленность растений, что защитит почву от перегрева прямыми солнечными лучами, а значит, уменьшит поток ик-излучения на растения от нагретой почвы и тем самым снизит потери влаги на испарение, усилит угнетение сорняков, затененных равномерно расположенными листьями, которые при этом более полно поглощают солнечную радиацию. Корневая система растений при таком их распределении пронизывает весь объем почвы между растениями. Итак, равнораспределение растений на поле позволяет эффективно использовать всю среду обитания для формирования повышенной продуктивности кукурузы (рис.7).

С огромным облегчением, развеявшим мои сомнения, нахожу у Дитера Шпаара [1] схему распределения семян кукурузы на поле, к которой я пришел при анализе продуктивности подсолнечника

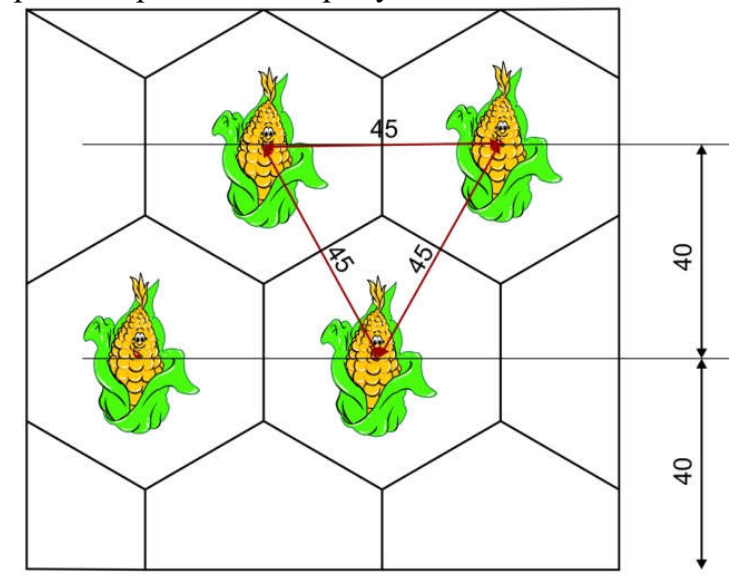

Рис.7. Вариант размещения растений при плотности сева 60 тыс. на га.

Таблица 1

Расчет иирины междурядий и расстояния между растениями в рядах при их равномерном размещении [1]

\begin{tabular}{|l|l|l|l|l|l|l|l|l|}
\hline \multirow{2}{*}{$\begin{array}{c}\text { Число } \\
\text { растений } \\
\text { на 1 м }\end{array}$} & \multicolumn{6}{|c|}{ Ширина междурядий, см } \\
\cline { 2 - 8 } & 28 & 29 & 30 & 31 & 32 & 33 & 34 & 35 \\
\hline Расстояния в ряду, см & 51 & 49 & 48 & 46 & 45 & 43 & 42 & 41 \\
\hline 7 & 45 & 43 & 42 & 40 & 39 & 38 & 37 & 36 \\
\hline 8 & 40 & 38 & 37 & 36 & 35 & 34 & 33 & 32 \\
\hline 9 & 36 & 34 & 33 & 32 & 31 & 30 & 29 & 29 \\
\hline 10 & 38 & 38 & 38 & 39 & 39 & 39 & 40 & 41 \\
\hline Расстояния между соседними растениями, см \\
\hline 7 & 36 & 36 & 37 & 37 & 37 & 38 & 39 & 39 \\
\hline 8 & 34 & 35 & 35 & 36 & 36 & 37 & 38 & 38 \\
\hline 9 & 33 & 34 & 34 & 35 & 36 & 36 & 37 & 38 \\
\hline 10 &
\end{tabular}

в зависимости от стояния растений перед уборкой. Дитер Шпаар пишет, что прежде чем начать применение такой технологии, необходимо ответить на следующие вопросы.

- Возможно ли ее комбинирование с имеющейся в хозяйстве уборочной техникой?

- Есть ли возможность равномерного распределения семян в ряду?

- Можно ли применять ленточную подкормку растений фосфором и другими удобрениями на глубину 5 см и на такое же расстояние сбоку от рядов?

- Приведет ли это к дополнительным затратам по уходу и удобрению посева?

Поскольку, количество растений на один гектар может существенно отличаться в зависимости от конечной цели выращивания (на силос, на зерно и т.д.), то Дитер Шпаар предлагает варианты размещения растений на поле при изменении их количества на одном м ${ }^{2}$ от 7 до 10 растений. Одно обязательное условие-равнораспределенность (табл. 1).

Такой посев требует соблюдения одинаковой ширины междурядий и расстояний между семенами в рядах с их разным расположением в соседних рядах. Это возможно только со специальными сеялками точного высева. Сегодня этот вопрос решен.

На рисунке 8 показано поле при равнораспределении растений кукурузы сеялкой GEO Seed.

Кроме того, разработчики сеялок, учитывая требования агротехнологии, начинают поставлять на рынок сеялки для строгого распределения семян со смещением одного ряда относительно другого (рис.9)

Исследования продуктивности кукурузы от обеспечения основными факторами жизни (тепло, свет, вода, минеральные элементы, воздух) активно начали проводиться в СССР во второй половине XX века. Это было мотивировано двумя причинами расширением посевов под кукурузу и появлением технологии гибридизации. Сегодня, с учетом изменения климата, кукурузного «бума», наличия в реестре Украины более 600 гибридов кукурузы, продвижения ее посевов в северные и западные регионы, исследования зависимости продуктивности ее от густоты стояния на поле исключительно интересны.

К сожалению, поиски таких исследований привели к материалам анализа продуктивности кукурузы в зависимости от дустоты стояния растений в ряду, поскольку они выполнены без варианта размещения их на поле при разных величинах междурядья, т.е. все они выполнены при междурядье 70 cм. Тем не менее, результаты исследования А.Андриенко и М.Ромашенко (2013) [2] дают ответы по морфологии кукурузы в зависимости от густоты стояния и еще раз подтверждают, что кукуруза по продуктивности избирательна к зоне возделывания, вегетативному периоду и к способности противостоять засухе. Как и следовало ожидать, при уплотнении семян кукурузы в ряду выше оптимального, в силу ужесточения конкуренции за основные факторы жизни выход зерна с кочана снижается в $1,5-1,8$ раза из-за уменьшения самого кочана и количества зерен в кочане и массы 1000 шт. семян. 



Рис. 8. Поле при равнораспределении растений кукурузы сеялкой GEO Seеd.

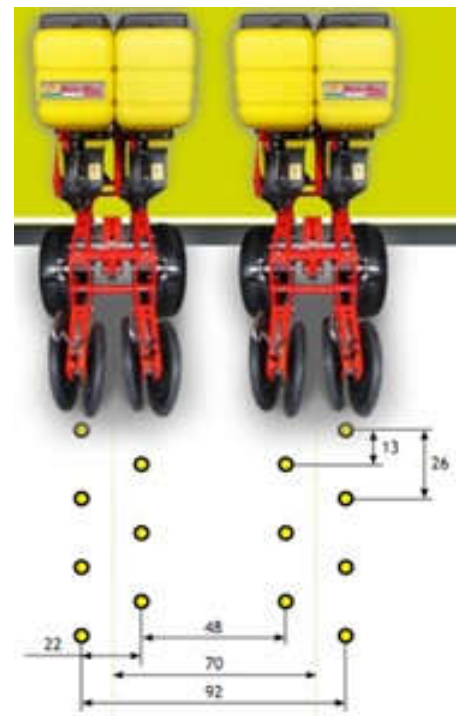

Рис.9. Схема высева семян сеялкой TWIN [4].
Но, как известно, величина урожая определяется продуктивностью всех растений с единицы площади поля. В этой связи приведем два графика, один по влиянию густоты стояния растений на урожайность для разных по времени вегетации гибридов кукурузы (рис.10), а второй по влиянию потенциала семян гибридов и их засухоустойчивости (рис.11).

Анализ гистограмм, приведенных на рисунках 10 и 11, позволяет сделать следующие выводы.

1.При междурядье 70 см густота сева кукуpyзы для раннеспелых гибридов может быть выше 80 mblc./2a.

2.Оптимальное количество растений на один гектар для среднеранних и среднеспелых гибридов (FAO 260-320) составляет 80 mbl./2a.

Засухоустойчивые среднеспелые гибриды также дают наивысшую урожайность при густоте стояния перед уборкой 80 mыс./2a. Еще раз оговоримся, что это при междурядье $70 \mathrm{~cm}$.

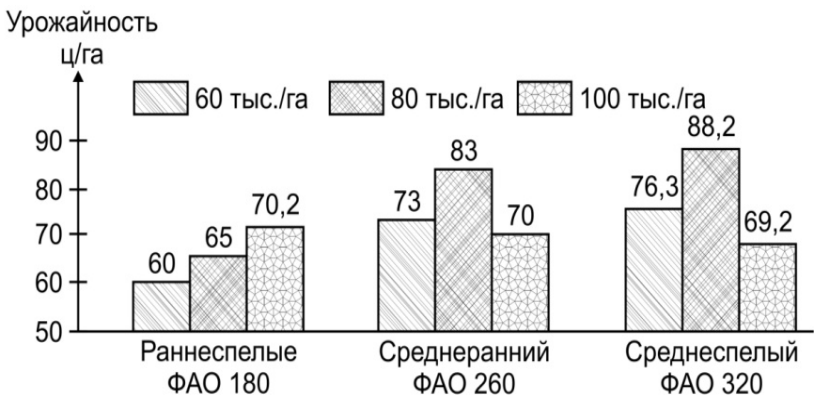

Рис.10. Урожайность кукурузы в зависимости от густоты стояния растений и скороспелости [2].

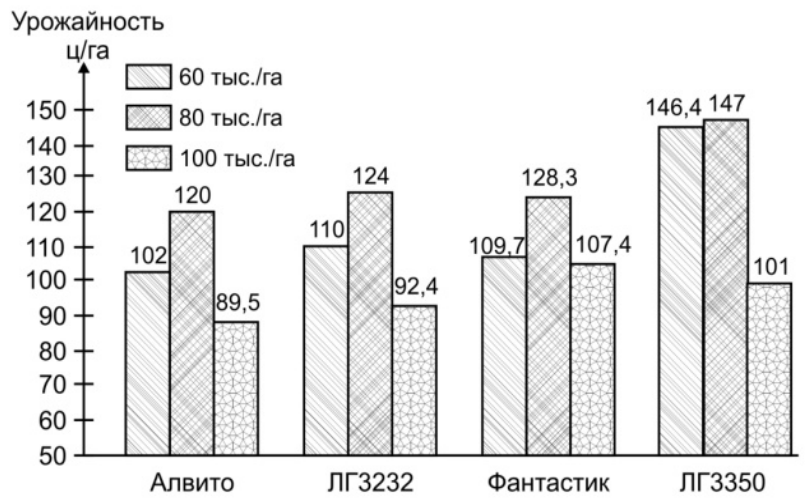

Рис.11. Урожайность различных гибридов кукурузы в зависимости от густоты стояния перед уборкой [2].

Рассмотрим сравнение продуктивности кукурузы при междурядье 70 см и при равно распределенном размещении растений на поле. 
Как уже отмечалось, ширина междурядий для кукурузы имеет особо важное значение, ибо начальные фазы развития кукурузы протекают медленно, позднее смыкание дает возможность сорнякам беспрепятственно использовать незатененную поверхность поля для собственного развития. Так Дитер Шпаар видит преимущества сужения междурядий в следующем: питания;

- лучшее распределение растений по площади

- более равномерное поглощение растениями питательных веществ из всего объема почвы;

- более полное использование внесенных удобрений;

- более раннее смыкание рядов и улучшение микроклимата в посеве;

- пониженная эрозия почвы;

- сокращение позднего засорения посева;

- снижение затрат на гербициды;

- уменьшение остаточного количества нитратов в почве после уборки;

- повышенная устойчивость к засухе.

Опыты в Центральной Германии (земля Тюрингия) показали, что особенно компактные низкорослые гибриды кукурузы положительно реагируют при выращивании с шириной междурядий $30 \mathrm{~cm}$. В этих опытах отмечалось изменение микроклимата внутри стеблестоя - повышение ночных температур на $5^{\circ} \mathrm{C}$ (рис. 12 ).

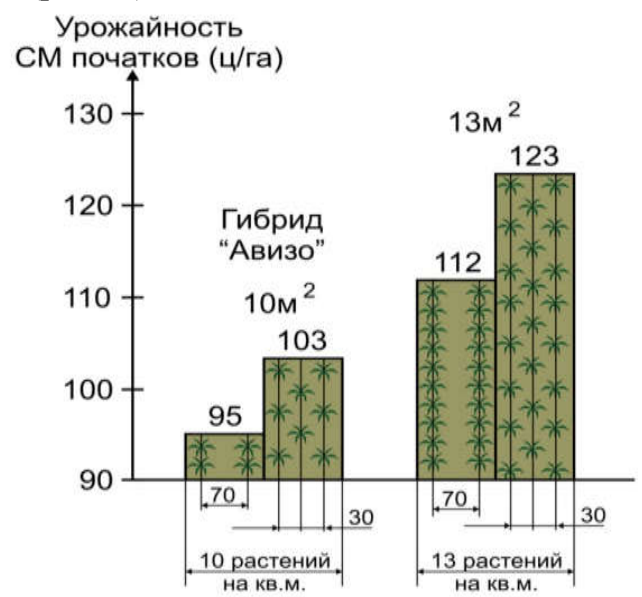

Рис.12. Влияние на урожсайность (СМ початков) кукурузы при изменении междурядья и густоты стояния [1].

Опыты были проведены на низкорослой кукуpyзe на силос. Увеличение массы початков (СМ) при междурядье 30 см с соответствующим равномерным распределением при севе дает основание предполагать, что при выращивании кукурузы на зерно снижение величины междурядья также приведет к повышению урожая.

Именно это подтвердили исследования, выполненные Ткаличем Ю.И. и др. (2013 г.) [3]. Исследования были выполнены по трем программам.

Сравнение продуктивности кукурузы при разных вариантах распределения растений на поле без какой-либо обработки. Результаты исследования приведены на рисунке 13. Как и следовало ожидать, урожайность при равно распределенном варианте размещения растений оказалась выше, чем при междурядье 70 см при равном количестве растений на гектар перед уборкой.

Это можно объяснить не только равномерностью обеспечения растений питанием, влагой и светом, но и тем, что биологическая засоренность при равномерном распределении растений на поле угнеталась растениями за счет конкуренции с сорняками, прежде всего за освещенность.

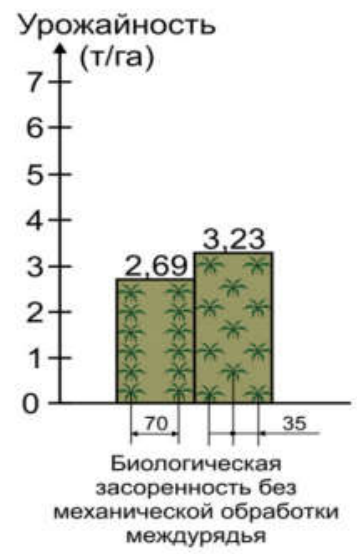

Рис.13. Урожайность зерна кукурузы в зависимости от способа сева и средств контроля сорняков [3].

1.Условия испытания остались такие же, как и в первом случае, но была проведена двукратная механическая междурядная обработка для уничтожения сорняков на поле с междурядьем $70 \mathrm{~cm}$. На поле с равно распределенным размещением растений сорняк не удалялся. Результаты испытания приведены на рисунке 14.

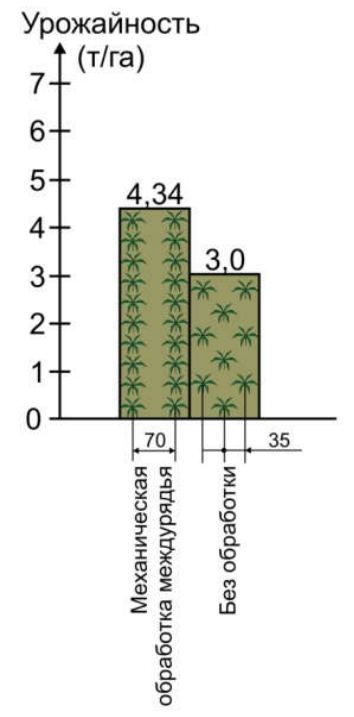

Рис.14. Урожайность зерна кукурузы в зависимости от способа сева и средств контроля сорняков [3].

Результаты, приведенные на рисунке 14, убедительно показывают недополучение урожая при отсутствии контроля за сорняками.

2.Программа третьего испытания включала механическую обработку междурядья 70 cм, отсутствие механической обработки от сорняков на поле с 


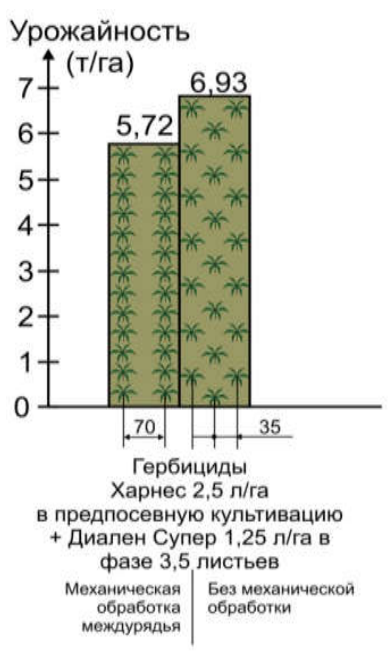

Рис. 15. Урожайность зерна кукурузы в зависимости от способа сева и средств контроля сорняков [3].

равно распределенным размещением растений, но с обработкой обоих полей с применением гербицидов «Харнес» 2,5 л/га под предпосевную культивацию
+ «Диале-Супер» 1,25 л/га в фазе 3-5 листьев. Результаты испытания приведены на рисунке 15 .

Результаты испытаний в этом случае убедительно доказали, что продуктивность кукурузы на зерно при равном распределении на поле, даже при отсутствии междурядной обработки и при целевой обработке гербицидами, заметно выше, чем при той же обработке гербицидами и плюс механической борьбе с сорняком при междурядье $70 \mathrm{~cm}$.

Приведенные результаты легко объясняются, ибо равномерное распределение солнечной энергии, влаги, воздуха, питательных веществ создают максимально продуктивную среду обитания каждому отдельному растению на поле, а оптимальная густота их стояния - мощный фактор продуктивности всего поля и надежное препятствие развитию сорняков.

Уважаемый читатель, вышеизложенный материал показал принципы подхода к распределению растений кукурузы на поле, естественно, что он «работает» и на других культурах. О подсолнечнике и сое будут следующие публикации.

\section{ЛИТЕРАТУР}

1. Шиаар Д. Кукуруза: выращивание, уборка, хранение и использование. - К.: Издательский дом «Зерно», 2012. - 464 с.: ил.

2. А. Андрієнко, канд.. с.-г. наук, М. Романенко, канд.. с.-г. наук, менеджери з розвитку продуктів, компанія «Лімагрейн». Густота як фактор продуктивності кукурудзи./Андрієнко А., Романенко М.// Пропозичія. -2013. - № (213) 3/13. - С. 59.

3. Ю. Ткаліч, канд.. с.-г. наук, О. Шевченко, канд.. с.-г. наук, В. Матюха, канд.. с.-г. наук, С.Кравець ДУ Інститут сільського господарства степової зони НААНУ. Вузькі міжряддя на кукурудзі./Ткаліч Ю., Шевченко О., Матюха В., Кравець С.// Пропозиція. - 2013. - № (215) $5 / 13 .-$ C. 76

4. Сівалки TWIN: створені для врожаю, сумірного із площею посіву.// Агроном №1. - 2015. - февраль. - С. 210.

Надійшла 13.10.2015. До друку 25.10.2015

Адреса для переписки:

ООО «Спецэлеватормельмаш»

Украина, г.Харьков, ул.Исполкомовская, 32

Тел./факс: (057) 3738060, (050) 1575740

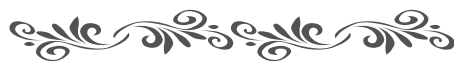

Email: specmash@imperija.com, http://agro.imperija.com

DOI:

УДК 664.6/.7

С.Ю. МИКОЛЕНКО, канд. техн. наук, доцент ${ }^{1}$, Ю.О. ЧУРСІНОВ, д-р техн. наук, професор ${ }^{1}$,

В.Ю. СОКОЛОВ, аспірант ${ }^{1}$, А.М. ПУГАЧ, канд. техн. наук, доцент ${ }^{1}$, С.Ю. ДІДЕНКО, канд. с.-г. наук ${ }^{2}$

${ }^{1}$ Дніпропетровський державний аграрно-економічний університет, М. Дніпропетровськ

2 Лабораторія якості зерна, Харківський інститут рослинництва ім. В.Я. Юр'єва НААН України, м. Харків

\section{ВПЛИВ ПЛАЗМОХІМІЧНО АКТИВОВАНОЇ ВОДИ НА ВУГЛЕВОДНО-АМІЛАЗНИЙ КОМПЛЕКС ЗЕРНА ПШЕНИЦІ}

\footnotetext{
Анотація

В статті показано вплив плазмохімічно активованої води на особливості процесу вологотеплової обробки з огляду на зміни крохмалю зерна пшениці та активність амілолітичних ферментів, присутніх у зерні. Встановлено, щзо плазмохімічно активована вода зі збільшенням тривалості обробки викликає зміну активності к-амілази зерна пшениці.

Визначено вплив води, підданої дії контактної нерівноважної плазми, на властивості пшеничного крохмалю за допомогою амілографа.

Встановлено особливості перебігу вологотеплової обробки зерна пшениці і перетворення високомолекулярних сполук у випадку застосування плазмохімічно активованої води.

Показано вплив води, підданої дї контактної нерівноважної плазми, на мікрофлору зерна під час його гідротермічної обробки.

Розглянуто можливість використання плазмохімічно активованої води у технології виробництва цільнозернових продуктів.

Ключові слова: зерно пшениці, вологотеплова обробка, вуглеводно-амілазний комплекс, вода, піддана дї контактної нерівноважної плазми.
} 